Article

\title{
A New Cytotoxic Sesquiterpene Quinone Produced by Penicillium sp. F00120 Isolated from a Deep Sea Sediment Sample
}

Xiuping Lin ${ }^{1}$, Xuefeng Zhou ${ }^{1}$, Fazuo Wang ${ }^{1}$, Kaisheng Liu ${ }^{2}$, Bin Yang ${ }^{1}$, Xianwen Yang ${ }^{1}$, Yan Peng ${ }^{1}$, Juan Liu ${ }^{1}$, Zhe Ren ${ }^{2}$ and Yonghong Liu ${ }^{1, *}$

1 Key Laboratory of Marine Bio-Resources Sustainable Utilization, Guangdong Key Laboratory of Marine Materia Medica, RNAM Center for Marine Microbiology, South China Sea Institute of Oceanology, Chinese Academy of Sciences, Guangzhou 510301, China;

E-Mails: xiupinglin@hotmail.com (X.L.); xfzhou@scsio.ac.cn (X.Z.); wangfazuo@scsio.ac.cn (F.W.); bingo525@163.com (B.Y.); xwyang@scsio.ac.cn (X.Y.); py00_2006@126.com (Y.P.); ljuan2010@qq.com (J.L.)

2 Biomedicine Research and Development Center of Jinan University, Guangzhou 510632, China; E-Mails: liukaisheng1987@163.com (K.L.); rz62@163.com (Z.R.)

* Author to whom correspondence should be addressed; E-Mail: yonghongliu@scsio.ac.cn; Tel.: +86-020-8902-3244; Fax: +86-020-8445-1672.

Received: 28 November 2011; in revised form: 26 December 2011 / Accepted: 9 January 2012 / Published: 12 January 2012

\begin{abstract}
A new fungal strain, displaying strong toxic activity against brine shrimp larvae, was isolated from a deep sea sediment sample collected at a depth of $1300 \mathrm{~m}$. The strain, designated as F00120, was identified as a member of the genus Penicillium on the basis of morphology and ITS sequence analysis. One new sesquiterpene quinone, named penicilliumin A (1), along with two known compounds ergosterol (2) and ergosterol peroxide (3), were isolated and purified from the cultures of F00120 by silica gel column, Sephadex LH-20 column, and preparative thin layer chromatography. Their structures were elucidated by detailed nuclear magnetic resonance (NMR) and mass spectroscopic (MS) analysis as well as comparison with literature data. The new compound penicilliumin A inhibited in vitro proliferation of mouse melanoma (B16), human melanoma (A375), and human cervical carcinoma (Hela) cell lines moderately.
\end{abstract}

Keywords: Penicillium sp. F00120; sesquiterpene quinone; cytotoxic; deep sea sediment; penicilliumin A 


\section{Introduction}

In recent years, marine microbes have received growing attention as the sources for bioactive metabolites. As a result of adaptation to the cold, high-pressure, low-nutrition, no light and local high temperature, high salt and other extreme ocean environments, marine microbes have formed unique genetic backgrounds and metabolic pathways [1]. The rich diversity of new bioactive compounds produced by these organisms suggests their importance as potential sources of pharmaceutical leads [2-5]. In particular, marine fungi have shown promising potential to produce a broad variety of bioactive metabolites with novel structures, and so far have provided more than 1000 new natural products, including polyketides, alkaloids, terpenoids, peptides, prenylated polyketides, shikimate-derived metabolites, and lipids [6-9]. Of these new natural products, 16\% were isolated from marine sediment-derived fungi. The deep sea is emerging as a new and interesting source of such microbes, however, only a handful of reports have described new metabolites from fungi derived from this habitat. Moreover, all were obtained from deep sea sediments [8]. Plenty of secondary metabolites from marine fungi have been demonstrated to show significant cytotoxicity against tumor cell lines [2,8].

In this work, we describe the fungal strain F00120, which was isolated from a deep sea sediment sample and exhibited strong toxic activity against brine shrimp larvae. The isolate was identified as a member of the genus Penicillium on the basis of taxonomic experiments. One new sesquiterpene quinone (1), along with two known sterols $(\mathbf{2}, \mathbf{3})$, were isolated and purified from this marine fungus. Their structures were determined by nuclear magnetic resonance (NMR) spectroscopy and mass spectrometry (MS) analysis as well as comparison with literature data. The new sesquiterpene quinone displayed moderate cytotoxic activity against mouse melanoma (B16), human melanoma (A375), and human cervical carcinoma (Hela) cells.

\section{Results and Discussion}

\subsection{Characterization and Identification of Isolated Strain F00120}

A fungal strain, F00120, which was isolated from a deep sea sediment sample collected in the northern South China Sea at a depth of $1300 \mathrm{~m}$, displayed strong toxic activity against brine shrimp larvae. At a concentration of $20 \mathrm{mg} / \mathrm{mL}$, the EtOAc extract of the fungal culture had a lethality rate of $95 \%$ to brine shrimp nauplii. On CA (Czapek's agar) medium, after 7 days of growth at $25{ }^{\circ} \mathrm{C}$, colonies were $39-41 \mathrm{~mm}$ in diameter, showed good sporulation, were mainly green at the centre and had a white periphery with a regular margin, whilst the reverse was dominated by a pale green color (Figure 1a). After 14 days of growth at $25{ }^{\circ} \mathrm{C}$, colonies were $74-75 \mathrm{~mm}$ in diameter, displayed very good sporulation, were dominated by a deep yellowish green with a pale green/white edge and a light green/gray reverse (Figure 1d). On SA (Sabourand's agar) medium, after 7 days of growth at $25{ }^{\circ} \mathrm{C}$, colonies were 48-50 $\mathrm{mm}$ in diameter, showed good sporulation, had a very light green centre surrounded by a white edge with a regular margin and a reverse dominated by a pale orange-yellow color (Figure 1b). After 14 days of growth at $25{ }^{\circ} \mathrm{C}$, colonies were $82-84 \mathrm{~mm}$ in diameter, presented good sporulation, were dominated by very light green centre, with a white edge, and a reverse that was light orange-yellow in color and, irregularly wrinkled (Figure 1e). On PDA (potato dextrose agar) medium, after 7 days of growth at $25^{\circ} \mathrm{C}$, colonies were $45-50 \mathrm{~mm}$ in diameter, displayed very good 
sporulation, were mainly deep green at the centre and surrounded by a white edge with a regular margin whilst the reverse was dominated by yellowish-gray, pale yellow exudate droplets (Figure 1c). After 14 days of growth at $25^{\circ} \mathrm{C}$, colonies were $84-86 \mathrm{~mm}$ in diameter, exhibited abundant sporulation, had a deep green centre surrounded by a very light yellow green edge, with a reverse dominated by a brilliant yellow green, notably the exudate droplets had disappeared (Figure 1f).

Figure 1. Colony appearance and micromorphology of Penicillium sp. F00120. (a-c) Colony appearance after 7 days at $25{ }^{\circ} \mathrm{C}$ (a, CA; b, SA; c, PDA); (d-f) Colony appearance after 14 days at $25^{\circ} \mathrm{C}(\mathrm{d}, \mathrm{CA}$; e, SA; f, PDA); (g) Conidiophore under light microscope; (h) Conidiophore under SEM; (i) Conidia under light microscope; (j) Conidia as seen using SEM. Bars: $10 \mu \mathrm{m}(\mathbf{g}-\mathbf{i})$ and $1 \mu \mathrm{m}(\mathbf{j})$.
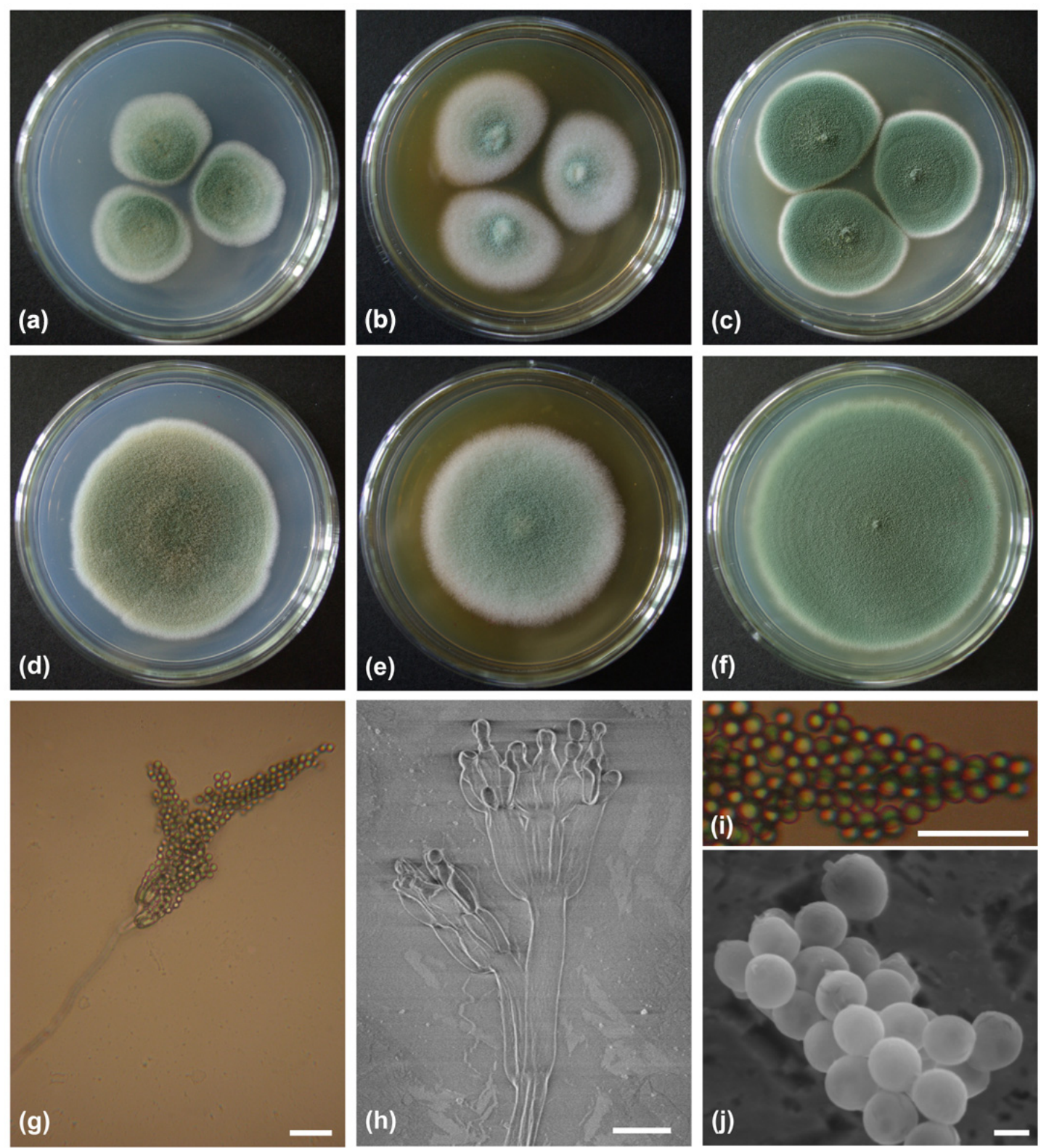

Scanning Electron Microscopy (SEM) revealed the penicilli were biverticillate (terverticillate), with smooth-walled to finely roughened stipes, $109.2-354.5 \mu \mathrm{m}$ in length, and bore 2-3 smooth-walled to finely roughened rami measuring $10.0-27.5($ mean $=20) \times 3.8-5.0($ mean $=4.3) \mu \mathrm{m}$. Metulae were 
smooth-walled and cylindrical measuring 7.5-13.3 (mean $=10.5) \times 3.8-5.8($ mean $=4.8) \mu \mathrm{m}$. Phialides were found to be smooth-walled and flask-shaped, 6.3-17.5 (mean = 11.6) $\times 3.3-5.0$ $($ mean $=4.0) \mu \mathrm{m}$, with rather long collula $(1.5-2 \mu \mathrm{m})$. Conidia were green and globose to subglobose when mature, 2.2-3.2 (mean $=2.5) \mu \mathrm{m}($ Figure $1 \mathrm{~g}-\mathrm{j})$.

ITS1-5.8S-ITS2 sequence region (585 basepairs (bp), accession number JN380201) of strain F00120 was amplified by PCR and DNA sequencing showed it shared significant homology to several species of Penicillium, with sequence identities ranging from 100 to $99 \%$. A phylogenetic tree was constructed, using the neighbor-joining method based on similarity of a 584-bp consensus length of ITS1-5.8S-ITS2 sequence (Figure 2). It showed that strain F00120 formed a monophyletic group with Penillium chrysogenum, Penillium commune, Penillium dipodomyicola, Penicillium citrinum, and Penicillium vinaceum, and that its closest neighbor was P. chrysogenum T16 (HQ262509). On the basis of its morphological property and ITS sequence, the fungus strain F00120 clearly belongs to the genus Penicillium, and was designated as Penicillium sp. F00120.

Figure 2. Neighbor-joining tree based on ITS1-5.8S-ITS2 sequences, showing phylogenetic relationship between strain F00120 and related Penicillium species. Numbers at nodes indicate bootstrap values from 1000 replicates. GenBank accession numbers are given in parentheses. Bar: $0.05 \%$ sequence divergence.

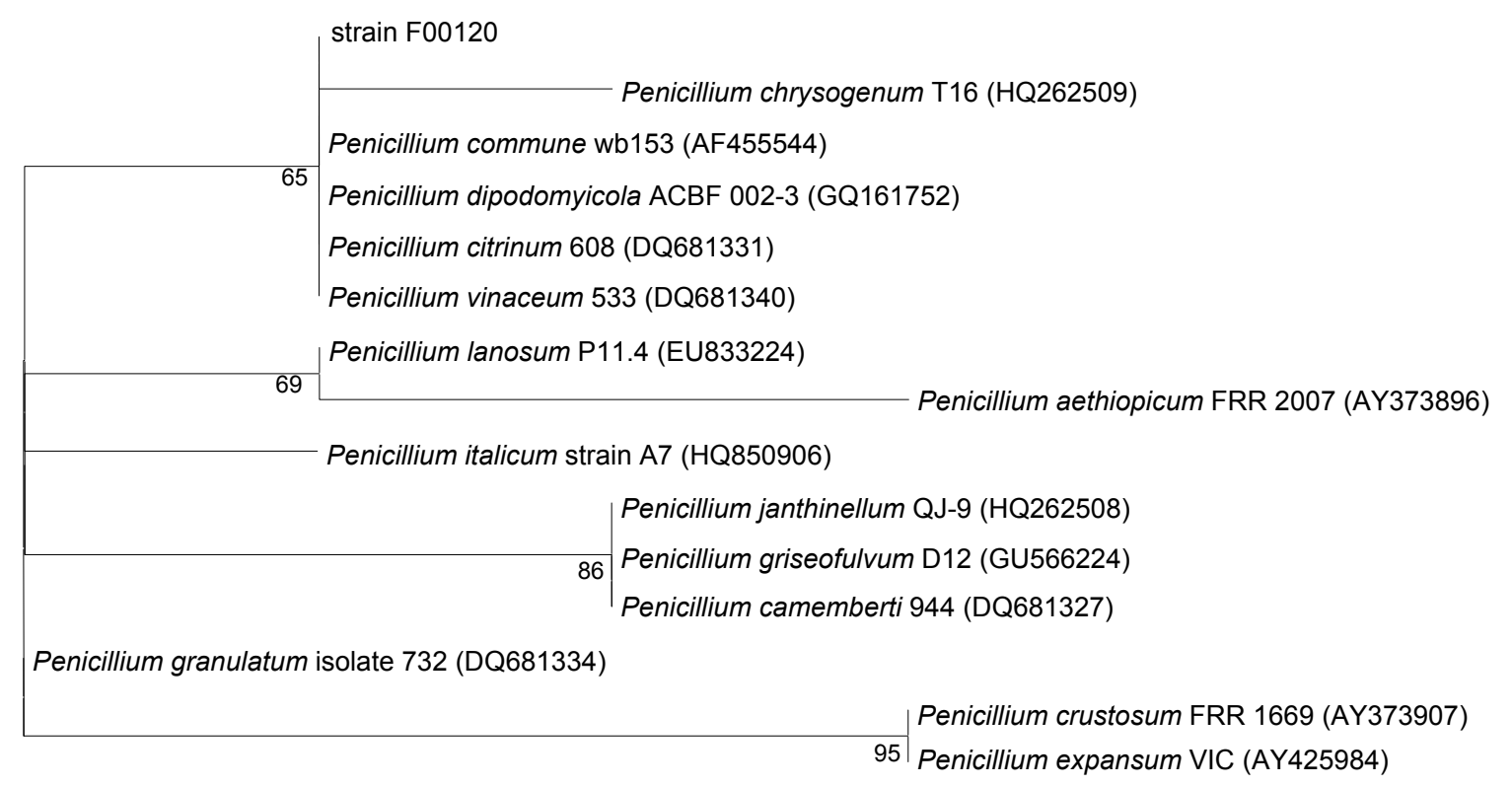

0.0005

\subsection{Structure Elucidation}

Penicilliumin A was obtained as white crystalline solid, $[\alpha]_{\mathrm{D}}^{20}$ : $-0.008\left(c 0.85, \mathrm{CHCl}_{3}\right)$. The IR spectrum possessed absorptions for hydroxyl groups $\left(3436 \mathrm{~cm}^{-1}\right)$ and carbonyl groups $\left(1683 \mathrm{~cm}^{-1}\right)$. It was analyzed for $\mathrm{C}_{22} \mathrm{H}_{32} \mathrm{O}_{4}$ by a combination of HREIMS ( $\mathrm{m} / \mathrm{z} 360.2296[\mathrm{M}]^{+}$, calcd 360.2295), ${ }^{13} \mathrm{C}$ NMR and DEPT spectra indicating 7 degrees of unsaturation. The ${ }^{1} \mathrm{H}$ NMR spectrum exhibited three methyl signals on quaternary carbons at $\delta_{\mathrm{H}} 0.58,0.76$, and 0.86 (each $3 \mathrm{H}$, s), a pair of hydroxylmethylene protons at $\delta_{\mathrm{H}} 4.44(\mathrm{~d}, J=1.7 \mathrm{~Hz})$ and $4.54(\mathrm{~d}, J=1.7 \mathrm{~Hz})$, and three olefinic 
protons at $\delta_{\mathrm{H}} 4.26(\mathrm{br} \mathrm{s}), 4.75(\mathrm{br} \mathrm{s})$, and $6.82(\mathrm{~s})$. The ${ }^{13} \mathrm{C}$ NMR and DEPT spectra showed signals representing three methyls $\left(\delta_{\mathrm{C}} 15.0,21.5,33.6\right.$, each $\left.\mathrm{CH}_{3}\right)$, one oxygenated methylene carbon $\left(\delta_{\mathrm{C}} 59.7\right.$ $\left.\mathrm{CH}_{2}\right)$ and one oxygenated tertiary carbon $\left(\delta_{\mathrm{C}} 77.0 \mathrm{C}\right)$, four olefinic carbons $\left(\delta_{\mathrm{C}} 107.0 \mathrm{CH}_{2}, 134.3 \mathrm{CH}\right.$, $148.9 \mathrm{C}, 150.8 \mathrm{C}$ ), and two ketone carbonyl carbons $\left(\delta_{\mathrm{C}} 201.1 \mathrm{C}, 196.5 \mathrm{C}\right)$. The ${ }^{1} \mathrm{H}$ and ${ }^{13} \mathrm{C} \mathrm{NMR}$ spectroscopic data of this compound (Table 1) resembled those of tauranin, containing the same sesquiterpene quinone carbon skeleton [10]. Tandem EI-MS produced a fragmentation ion at $m / z 205$ $\left[\mathrm{C}_{15} \mathrm{H}_{25}\right]$ which confirmed the sesquiterpene moiety of penicilliumin $\mathrm{A}$ was the same as that in tauranin. The major differences were the absence of one double bond and position of one hydroxyl group in quinone moiety of penicilliumin A. In the HMBC spectrum (Figure 3), the protons of H- $6^{\prime}$ $\left(\delta_{\mathrm{H}} 2.97, \mathrm{~d}, J=1.6 \mathrm{~Hz} ; 3.12, \mathrm{~d}, J=1.6 \mathrm{~Hz}\right)$ showed correlations with $\mathrm{C}-1^{\prime}\left(\delta_{\mathrm{C}} 77.0\right), \mathrm{C}-2^{\prime}\left(\delta_{\mathrm{C}} 201.1\right)$, C-4' $\left(\delta_{\mathrm{C}} 150.8\right)$, and C-5' $\left(\delta_{\mathrm{C}} 196.5\right)$, supporting the absence of the double bond at C-1'and C- $6{ }^{\prime}$. Other HMBC correlations of the signals $\mathrm{H}-9\left(\delta_{\mathrm{H}} 1.79\right), \mathrm{H}-14\left(\delta_{\mathrm{H}} 1.80,1.89\right)$, and H-3' $\left(\delta_{\mathrm{H}} 6.82\right)$ with C-1 $1^{\prime}$ $\left(\delta_{\mathrm{C}} 77.0\right)$, together with the chemical shifts of C-1', C-2', C-6', and C-14, also suggest the presence of a hydroxyl group at $\mathrm{C}-1^{\prime}$. Due to the $\beta$-orientation of $\mathrm{CH}_{3}-13$ and $\alpha$-configuration of $\mathrm{H}-5$ [10], the NOESY correlations of the signals H-9 $\left(\delta_{\mathrm{H}} 1.79\right)$ with $\mathrm{H}-5\left(\delta_{\mathrm{H}} 1.12, \mathrm{dd}, J=13,2.5 \mathrm{~Hz}\right), \mathrm{H}-12\left(\delta_{\mathrm{H}} 0.86, \mathrm{~s}\right)$ with $\mathrm{H}-13\left(\delta_{\mathrm{H}} 0.58, \mathrm{~s}\right)$, and $\mathrm{H}-13\left(\delta_{\mathrm{H}} 0.58, \mathrm{~s}\right)$ with $\mathrm{H}-14\left(\delta_{\mathrm{H}} 1.80,1.89\right)$ revealed the $\alpha$-configuration of $\mathrm{H}-9$. Thus, penicilliumin A was elucidated as the new compound penicilliumin A and its relative stereochemistry is as shown in Figure 4.

Table 1. ${ }^{13} \mathrm{C}$ and ${ }^{1} \mathrm{H}$ NMR data $\left(500 \mathrm{MHz}, \mathrm{CDCl}_{3}\right)$ for compound $\mathbf{1}$.

\begin{tabular}{|c|c|c|}
\hline Position & $\delta_{\mathrm{C}}(\mathrm{m})$ & $\delta_{\mathrm{H}}(\mathrm{m} . J \mathrm{~Hz})$ \\
\hline \multirow[t]{2}{*}{1} & $38.7 \mathrm{CH}_{2}$ & $1.05 \mathrm{~m}$ \\
\hline & & $1.62 \mathrm{~m}$ \\
\hline \multirow[t]{2}{*}{2} & $19.3 \mathrm{CH}_{2}$ & $1.49 \mathrm{~m}$ \\
\hline & & $1.52 \mathrm{~m}$ \\
\hline \multirow[t]{2}{*}{3} & $42.0 \mathrm{CH}_{2}$ & $1.16 \mathrm{~m}$ \\
\hline & & $1.38 \mathrm{~m}$ \\
\hline 4 & $33.5 \mathrm{C}$ & / \\
\hline 5 & $55.6 \mathrm{CH}$ & $1.12 \mathrm{dd}(13,2.5)$ \\
\hline \multirow[t]{2}{*}{6} & $24.6 \mathrm{CH}_{2}$ & $1.27 \mathrm{~m}$ \\
\hline & & $1.74 \mathrm{~m}$ \\
\hline \multirow[t]{2}{*}{7} & $38.1 \mathrm{CH}_{2}$ & $1.89 \mathrm{~m}^{\mathrm{a}}$ \\
\hline & & 2.29 ddd $(12.5,6.5,3.5)$ \\
\hline 8 & $148.9 \mathrm{C}$ & / \\
\hline 9 & $50.5 \mathrm{CH}$ & $1.79 \mathrm{~m}^{\mathrm{b}}$ \\
\hline 10 & $39.9 \mathrm{C}$ & / \\
\hline 11 & $21.5 \mathrm{CH}_{3}$ & $0.76 \mathrm{~s}$ \\
\hline 12 & $33.6 \mathrm{CH}_{3}$ & $0.86 \mathrm{~s}$ \\
\hline 13 & $15.0 \mathrm{CH}_{3}$ & $0.58 \mathrm{~s}$ \\
\hline \multirow[t]{2}{*}{14} & $34.7 \mathrm{CH}_{2}$ & $1.80 \mathrm{~m}^{\mathrm{b}}$ \\
\hline & & $1.89 \mathrm{~m}^{\mathrm{a}}$ \\
\hline \multirow[t]{2}{*}{15} & $107.0 \mathrm{CH}_{2}$ & $4.26 \mathrm{br} \mathrm{s}$ \\
\hline & & 4.75 br s \\
\hline
\end{tabular}


Table 1. Cont.

\begin{tabular}{lll}
\hline $1^{\prime}$ & $77.0 \mathrm{C}$ & $/$ \\
$2^{\prime}$ & $201.1 \mathrm{C}$ & $/$ \\
$3^{\prime}$ & $134.3 \mathrm{CH}$ & $6.82 \mathrm{~s}$ \\
$4^{\prime}$ & $150.8 \mathrm{C}$ & $/$ \\
$5^{\prime}$ & $196.5 \mathrm{C}$ & $/$ \\
$6^{\prime}$ & $53.0 \mathrm{CH}_{2}$ & $2.97 \mathrm{~d}(1.6)$ \\
& & $3.12 \mathrm{~d}(1.6)$ \\
& & $4.44 \mathrm{~d}(1.7)$ \\
$1^{\prime \prime}$ & $59.7 \mathrm{CH}_{2}$ & $4.54 \mathrm{~d}(1.7)$ \\
\hline
\end{tabular}

${ }^{\mathrm{a}, \mathrm{b}}$ Assignments with the same superscript in the same column may be interchanged.

Figure 3. Key NOESY and HMBC correlations of penicilliumin A (1).

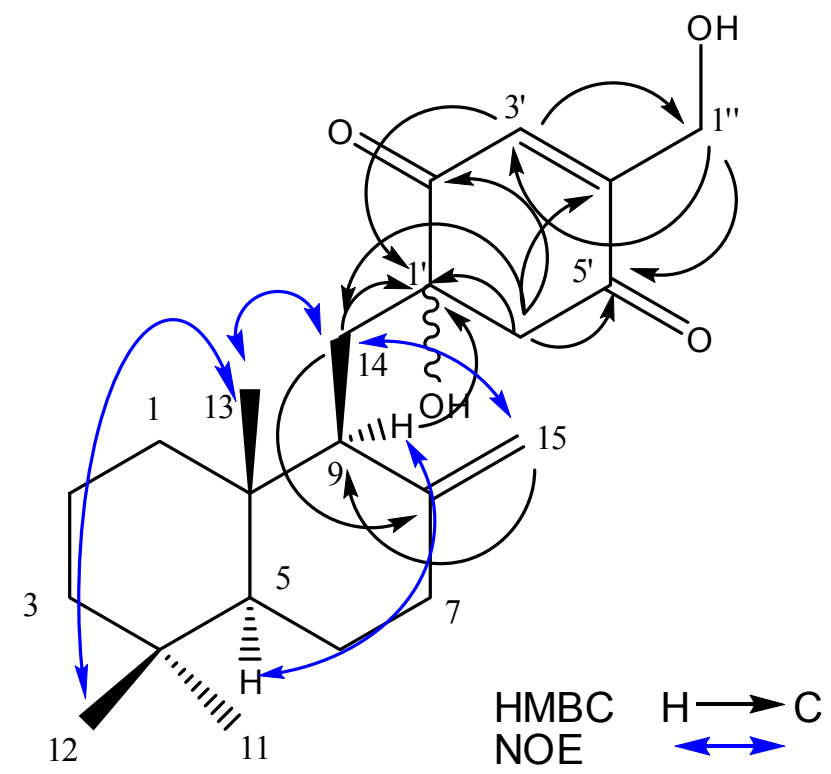

Figure 4. Structures of compound 1-3 from Penicillium sp. F00120.<smiles>C=C1CC[C@]2(I)[C@@H](I)CCC[C@]2(C)[C@H]1C[C@]1(C)CC(=O)C(CO)=CC1=O</smiles>

The structures of known compounds 2 and 3 (Figure 4) were confirmed by detailed NMR data comparison with those in literatures [11,12]. 


\subsection{Cytotoxic and Antiviral Activities of Penicilliumin A}

So far, 7 natural analogues of penicilliumin A have been reported. Among them, tauranin [10,13] and BE-40644 [14,15] displayed potent in vitro cytotoxic activity against cancer cells. In vitro cytotoxic effects of penicilliumin A was tested against three cancer cell lines-A375, B16 and Hela - using 3-(4,5-Dimethylthiazol-2-yl)-2,5-diphenyl-tetrazolium bromide (MTT) assay. The $\mathrm{GI}_{50}$ values were 22.88, 27.37, and 44.05 $\mu \mathrm{g} / \mathrm{mL}$, respectively. In this assay, A375 cells showed relatively higher susceptibility to penicilliumin A compared to Hela and B16 cells. Penicilliumin A was also evaluated for its antiviral activity against coxsackievirus B3 (CVB3), herpes simplex virus type I (HSV-1), and influenza A virus subtype $\mathrm{H} 5 \mathrm{~N} 3(\mathrm{~A} / \mathrm{H} 5 \mathrm{~N} 3)$ in vitro. The median toxic concentration $\left(\mathrm{TC}_{50}\right)$ values against the host cells Hela, African green monkey kidney (Vero), and Madin-Darby canine kidney (MDCK) cells were 40.72, 133.52, and $43.00 \mu \mathrm{g} / \mathrm{mL}$, respectively. However, penicilliumin A did not show antiviral activity against test virus strains, under its maximal atoxic concentration $\left(\mathrm{TC}_{0}\right)$. For further investigation of its cytotoxic activity, larger quantities of penicilliumin A are required. Optimization of fermentation conditions is currently under development by our research group to enable large scale production.

\section{Experimental Section}

\subsection{General Experimental Procedures}

MS data were acquired using a Thermo DSQ mass spectrometer. ${ }^{1} \mathrm{H}$ - and ${ }^{13} \mathrm{C}-\mathrm{NMR}$, and $2 \mathrm{D}$ NMR data were obtained with a Bruker Avance 500 spectrometer, with tetramethylsilane (TMS, $\delta 0.0 \mathrm{ppm}$ ) as the internal standard. The optical rotations were recorded on a 341 polarimeter. IR spectra were determined on a Nicolet 6700 FT-IR spectrometer. UV spectroscopic data were obtained on an UV-2501 PC spectrophotometer. Column chromatography (CC) was performed with silica gel (100-200 mesh; 300-400 mesh; Jiangyou Silica Gel Development, Inc., Yantai, China) and Sephadex LH-20 (Pharmacia). Thin layer chromatography (TLC, $0.1-0.2 \mathrm{~mm}$ or $0.3-0.4 \mathrm{~mm}$ ) was carried out with precoated silica gel plates (GF-254, Jiangyou Silica Gel Development, Inc., Yantai, China).

\subsection{Microbial Material}

The microorganism was obtained from the sediment of the northern South China Sea (Lat. $22^{\circ} 6.017^{\prime} \mathrm{N}$, Long. $119^{\circ} 17.440^{\prime} \mathrm{E}$ ) at a depth of $1300 \mathrm{~m}$. It was isolated on Gause's No. 1 synthetic medium (soluble starch $20 \mathrm{~g}, \mathrm{NaCl} 0.5 \mathrm{~g}, \mathrm{KNO}_{3} 1 \mathrm{~g}, \mathrm{~K}_{2} \mathrm{HPO}_{4} \cdot 3 \mathrm{H}_{2} \mathrm{O} 0.5 \mathrm{~g}, \mathrm{MgSO}_{4} \cdot 7 \mathrm{H}_{2} \mathrm{O} 0.5 \mathrm{~g}$, $\mathrm{FeSO}_{4} \cdot 7 \mathrm{H}_{2} \mathrm{O} 0.01 \mathrm{~g}$, agar $15 \mathrm{~g}$, sea water $1000 \mathrm{~mL}, \mathrm{pH}$ 7.4-7.6) and designated as strain F00120. It was stored on PDA slants at $4{ }^{\circ} \mathrm{C}$ and deposited at Research Center for Marine Microbes, Chinese Academy of Sciences (Guangzhou City), as SCSIO-F00120. The colony-forming and pigmentation properties of strain F00120 were examined on Czapek's agar (CA, consisted of sucrose $30 \mathrm{~g}, \mathrm{NaNO}_{3}$ $3 \mathrm{~g}, \mathrm{~K}_{2} \mathrm{HPO}_{4} 1 \mathrm{~g}, \mathrm{MgSO}_{4} \cdot 7 \mathrm{H}_{2} \mathrm{O} 0.5 \mathrm{~g}, \mathrm{KCl} 0.5 \mathrm{~g}, \mathrm{FeSO}_{4} 0.01 \mathrm{~g}, \mathrm{NaCl} 2.5 \mathrm{~g}$, agar $15 \mathrm{~g}$, distilled water $1000 \mathrm{~mL}$ ), Sabourand's agar (SA, consisted of dextrose $40 \mathrm{~g}$, peptone $10 \mathrm{~g}, \mathrm{NaCl} 2.5 \mathrm{~g}$, agar $15 \mathrm{~g}$, distilled water $1000 \mathrm{~mL}, \mathrm{pH}$ 5.6), and potato dextrose agar (PDA, consisted of potato $200 \mathrm{~g}$, dextrose $20 \mathrm{~g}, \mathrm{NaCl} 2.5 \mathrm{~g}$, agar $15 \mathrm{~g}$, distilled water $1000 \mathrm{~mL}$ ) after culturing for 7 and 14 days at $25^{\circ} \mathrm{C}$. 
Conidia morphology was examined of 7-day cultures grown on CA. Using the cover technique described previously [16,17], samples were observed with a Nikon Eclipse E600 light microscope and a Hitachi S-3400N scanning electron microscope. Genomic DNA isolation, PCR amplification of ITS region, sequence alignment, and phylogenetic tree construction of strain F00120 were performed as described previously [18,19].

Strain F00120 stored on PDA slants at $4{ }^{\circ} \mathrm{C}$ was cultured on PDA agar plates and incubated for 7 days. Seed medium (potato $200 \mathrm{~g}$, dextrose $20 \mathrm{~g}, \mathrm{NaCl} 2.5 \mathrm{~g}$, distilled water $1000 \mathrm{~mL}$ ) in $500-\mathrm{mL}$ Erlenmeyer flasks was inoculated with strain F00120 and incubated at $25{ }^{\circ} \mathrm{C}$ for $48 \mathrm{~h}$ on a rotating shaker $(180 \mathrm{rpm}$ ). Production medium of solid rice in $1000 \mathrm{~mL}$ flasks (rice $200 \mathrm{~g}, \mathrm{NaCl} 0.5 \mathrm{~g}$, distilled water $200 \mathrm{~mL}$ ) was inoculated with $10 \mathrm{~mL}$ seed solution. Flasks were incubated at $25^{\circ} \mathrm{C}$ under static stations and daylight. After 35 days, cultures from 10 flasks were harvested for the isolation of substances with cytotoxic activity.

\subsection{Extraction and Isolation}

The culture medium containing the mycelium was cut into small pieces, mixed with ethyl acetate (EtOAc) (3000 mL), and steeped for 1 day. The content was filtered under vacuum using a Buchner funnel and the extraction with EtOAc was repeated until exhaustion. The combined filtrates were washed with $5000 \mathrm{~mL}$ water to eliminate remaining sugar and starch. The organic phase was collected and evaporated $\left(40{ }^{\circ} \mathrm{C}\right)$ to remove EtOAc. An oily residue $(30.9 \mathrm{~g})$ was obtained, chromatographed on silica gel and eluted with a gradient of petroleum ether (PE)-EtOAc (1:0, 30:1, 20:1, 10:1, 5:1, 1:1, 0:1) to yield 9 fractions (Frs. A1-9). Fr. A7 (5.4 g) was further separated by silica gel column chromatography and eluted with PE-acetone (4:1), resulting in 8 fractions (Frs. E1-8). Fr. E1 (976.6 mg) was chromatographed on a Sephadex LH-20 column using $\mathrm{CHCl}_{3}-\mathrm{MeOH}(1: 1)$ to produce 6 fractions (Frs. F1-6). Then Fr. F4 (64.5 mg) was separated by Sephadex LH-20 (MeOH) to yield 3 fractions (Frs. I1-3). A further separation of Fr. I2 (41.9 mg) yielded penicilliumin A (1) (20 mg) by preparative thin layer chromatography using $\mathrm{CHCl}_{3}$-EtOAc $(3: 2)$ as developers. Fr. F4 was further separated by Sephadex LH-20 (MeOH) to yield compound $3(10 \mathrm{mg})$. Methanol was added to the residue of Fr. A5, and the mixture was stirred to yield pure white crystal of compound 2 (213 $\mathrm{mg})$.

Penicilliumin A (1): white crystalline solid; $[\alpha]_{\mathrm{D}}^{20}:-0.008\left(c 0.85, \mathrm{CHCl}_{3}\right)$; UV $\lambda_{\max }$ (cyclohexane) $\mathrm{nm}(\log \varepsilon): 237$ (4.22); IR (KBr) $v_{\max } 3436,1683 \mathrm{~cm}^{-1} ;{ }^{1} \mathrm{H}$ and ${ }^{13} \mathrm{C}$ NMR data, see Table 1. HRESI-MS $[\mathrm{M}]^{+} \mathrm{m} / z 360.2296$ (calcd. for $\mathrm{C}_{22} \mathrm{H}_{32} \mathrm{O}_{4}$ 360.2295), EI-MS: $m / z 360$ [M] $]^{+}$.

\subsection{Brine Shrimp Lethal Activity of Crude Extract of Fungal Culture and in vitro Cytotoxic and} Antiviral Effect of Penicilliumin A

Brine shrimp lethality test for nauplii was used to determine the toxicity of EtOAc extract of fungal culture as in the report of Solis et al. [20]. Cytotoxic effect of penicilliumin A was assayed against 3 tumor cell lines, including B16, A375, and Hela, according to previously described methods [19]. Antiviral activity against 3 virus strains CVB3, HSV-1, and A/H5N3 of this compound was evaluated by the cytopathic effect (CPE) inhibitory assay as described previously [21,22]. Cell lines Hela, Vero and MDCK were used as host cells of CVB3, HSV-1, and A/H5N3, respectively. 


\section{Conclusions}

A fungal strain, Penicillium sp. F00120, was isolated from a deep sea sediment sample during a screening program and the EtOAc extract displayed strong toxic activity against brine shrimp larvae. The identity of the isolate was determined by morphological and genetic analyses. One new sesquiterpene quinone penicilliumin A (1), and two known compounds ergosterol (2) and ergosterol peroxide (3), were isolated from the culture of solid-state fermentation of this strain. Penicilliumin A exhibited in vitro cytotoxic activity against B16, A375, and Hela cells.

\section{Acknowledgments}

This study was supported by the National Basic Research Program of China (973 Program, Nos. 2010CB833800 and 2011CB915503), Knowledge Innovation Program of Chinese Academy of Science (KSCX2-YW-G-073 and KSCX2-EW-G-12B), and National Natural Science Foundation of China (Nos. 30973679, 21172230, and 21002110), Guangdong Province-CAS Joint Research Program (2011B090300023).

\section{References}

1. Venter, J.C.; Remington, K.; Heidelberg, J.F.; Halpern, A.L.; Rusch, D.; Eisen, J.A.; Wu, D.; Paulsen, I.; Nelson, K.E.; Nelson, W.; et al. Environmental genome shotgun sequencing of the Sargasso Sea. Science 2004, 304, 66-74.

2. Mayer, A.M.; Gustafson, K.R. Marine pharmacology in 2005-2006: Antitumour and cytotoxic compounds. Eur. J. Cancer 2008, 44, 2357-2387.

3. Mayer, A.M.; Rodriguez, A.D.; Berlinck, R.G.; Fusetani, N. Marine pharmacology in 2007-8: Marine compounds with antibacterial, anticoagulant, antifungal, anti-inflammatory, antimalarial, antiprotozoal, antituberculosis, and antiviral activities; affecting the immune and nervous system, and other miscellaneous mechanisms of action. Comp. Biochem. Physiol. C Toxicol. Pharmacol. 2011, 153, 191-222.

4. Mayer, A.M.; Rodriguez, A.D.; Berlinck, R.G.; Hamann, M.T. Marine pharmacology in 2003-4: Marine compounds with anthelmintic antibacterial, anticoagulant, antifungal, anti-inflammatory, antimalarial, antiplatelet, antiprotozoal, antituberculosis, and antiviral activities; affecting the cardiovascular, immune and nervous systems, and other miscellaneous mechanisms of action. Comp. Biochem. Physiol. C Toxicol. Pharmacol. 2007, 145, 553-581.

5. Mayer, A.M.; Rodriguez, A.D.; Berlinck, R.G.; Hamann, M.T. Marine pharmacology in 2005-6: Marine compounds with anthelmintic, antibacterial, anticoagulant, antifungal, anti-inflammatory, antimalarial, antiprotozoal, antituberculosis, and antiviral activities; affecting the cardiovascular, immune and nervous systems, and other miscellaneous mechanisms of action. Biochim. Biophys. Acta 2009, 1790, 283-308.

6. Bugni, T.S.; Ireland, C.M. Marine-derived fungi: A chemically and biologically diverse group of microorganisms. Nat. Prod. Rep. 2004, 21, 143-163.

7. Proksch, P.; Putz, A.; Ortlepp, S.; Kjer, J.; Bayer, M. Bioactive natural products from marine sponges and fungal endophytes. Phytochem. Rev. 2010, 9, 475-489. 
8. Rateb, M.E.; Ebel, R. Secondary metabolites of fungi from marine habitats. Nat. Prod. Rep. 2011, 28, 290-344.

9. Saleem, M.; Ali, M.S.; Hussain, S.; Jabbar, A.; Ashraf, M.; Lee, Y.S. Marine natural products of fungal origin. Nat. Prod. Rep. 2007, 24, 1142-1152.

10. Wijeratne, E.M.; Paranagama, P.A.; Marron, M.T.; Gunatilaka, M.K.; Arnold, A.E.; Gunatilaka, A.A. Sesquiterpene quinones and related metabolites from Phyllosticta spinarum, a fungal strain endophytic in Platycladus orientalis of the Sonoran Desert. J. Nat. Prod. 2008, 71, 218-222.

11. Shirane, N.; Takenaka, H.; Ueda, K.; Hashimoto, Y.; Katoh, K.; Ishii, H. Sterol analysis of DMI-resistant and -sensitive strains of Venturia inaequalis. Phytochemistry 1996, 41, 1301-1308.

12. Krzyczkowski, W.; Malinowska, E.; Suchocki, P.; Kleps, J.; Olejnik, M.; Herold, E. Isolation and quantitative determination of ergosterol peroxide in various edible mushroom species. Food Chemistry 2009, 113, 351-355.

13. Kawashima, K.; Nakanishi, K.; Tada, M. Structure of tauranin. Tetrahedron Lett. 1964, 5, 1227-1231.

14. Torigoe, K.; Wakasugi, N.; Sakaizumi, N.; Suzuki, H.; Kojiri, K.; Suda, H. Antitumor substance BE-40644S. Jpn. Patent JPO 07-304762 A, 21 Novermber 1995.

15. Torigoe, K.; Wakasugi, N.; Sakaizumi, N.; Ikejima, T.; Suzuki, H.; Kojiri, K.; Suda, H. BE-40644, a new human thioredoxin system inhibitor isolated from Actinoplanes sp. A40644. J. Antibiot. 1996, 49, 314-317.

16. Kawato, M.; Shinobu, R. On Streptomyces herbaricolor sp. nov., supplement: A single technique for microscopical observation. Mem. Osaka Univ. Lib. Arts Educ. B Nat. Sci. 1959, 8, 114-119.

17. Zhou, Z.H.; Liu, Z.H.; Qian, Y.D.; Kim, S.B.; Goodfellow, M. Saccharopolyspora spinosporotrichia sp. nov., a novel actinomycete from soil. Int. J. Syst. Bacteriol. 1998, 48, 53-58.

18. Kjer, J.; Debbab, A.; Aly, A.H.; Proksch, P. Methods for isolation of marine-derived endophytic fungi and their bioactive secondary products. Nat. Protoc. 2010, 5, 479-490.

19. Lin, X.; Wen, Y.; Li, M.; Chen, Z.; Guo, J.; Song, Y.; Li, J. A new strain of Streptomyces avermitilis produces high yield of oligomycin A with potent anti-tumor activity on human cancer cell lines in vitro. Appl. Microbiol. Biotechnol. 2009, 81, 839-845.

20. Solis, P.N.; Wright, C.W.; Anderson, M.M.; Gupta, M.P.; Phillipson, J.D. A microwell cytotoxicity assay using Artemia salina (brine shrimp). Planta. Med. 1993, 59, 250-252.

21. Schmidtke, M.; Makarov, V.A.; Riabova, O.B.; Granik, V.G.; Wutzler, P. Novel [(biphenyloxy)propyl]isoxazole derivatives for inhibition of human rhinovirus 2 and coxsackievirus B3 replication. J. Antimicrob. Chemother. 2005, 55, 483-488.

22. Schmidtke, M.; Schnittler, U.; Jahn, B.; Dahse, H.M.; Stelzner, A. A rapid assay for evaluation of antiviral activity against coxsackie virus B3, influenza virus A, and herpes simplex virus type 1 . J. Virol. Methods 2001, 95, 133-143.

Samples Availability: Available from the authors.

(C) 2012 by the authors; licensee MDPI, Basel, Switzerland. This article is an open access article distributed under the terms and conditions of the Creative Commons Attribution license (http://creativecommons.org/licenses/by/3.0/). 